\title{
Effect of renal denervation on long-term outcomes in patients with resistant hypertension
}

\author{
Bo Liang ${ }^{1}$ (1), Yi Liang ${ }^{2}$ (D) Rui Li ${ }^{1}$ and Ning Gu${ }^{3^{*}}$ (D)
}

\begin{abstract}
Increasing studies strongly prove that renal denervation, a minimally invasive surgery, is a promising new non-drug treatment method that can effectively control blood pressure in patients with resistant hypertension, but the evaluation of the long-term blood pressure control effect of renal denervation for resistant hypertension is still lacking. Here, we critically review current long-term follow-up data about the use of renal denervation for $\mathrm{RH}$ to comprehensively evaluate the effectiveness of renal denervation for $\mathrm{RH}$, and to provide practical guidance for practitioners who are establishing a renal denervation service. Limited by the current research, many problems need to be solved before renal denervation is applied to $\mathrm{RH}$. In addition, ambulatory blood pressure should be the first choice for the evaluation of blood pressure. Finally, the continuous antihypertensive effect of renal denervation in different renal denervation systems also needs to be strictly compared.
\end{abstract}

Keywords: Hypertension, Renal denervation, Resistant hypertension, Intervention

\section{Introduction}

Resistance hypertension (RH) requires four or more antihypertensive agents to keep blood pressure (BP) below $130 / 80 \mathrm{mmHg}$ [1], which accounted for about 25\% [2, $3]$ among hypertension, a population health focus $[4,5]$. $\mathrm{RH}$ is a growing clinical condition worldwide associated with target-organ damage and poor prognosis compared to non-RH [6, 7]. Renal denervation (RDN) therapy for $\mathrm{RH}$ has traveled a storied path over the past decade, from unbridled enthusiasm to abrupt disillusionment, and now renewed but still cautious interest [8]. While we review the earlier criticisms of trial conduct and more broadly device-based therapies for hypertension, we may need to understand the implications of these clinical trials based on RDN therapy more systematically and

\footnotetext{
*Correspondence: guning@njucm.edu.cn

${ }^{3}$ Nanjing Hospital of Chinese Medicine Affiliated to Nanjing University of Chinese Medicine, Nanjing, China

Full list of author information is available at the end of the article
}

comprehensively. We previously summarized the typical clinical trials of RH treated with RDN in recent years and found that RDN therapy seems to be safe and reliable for $\mathrm{RH}$ although there are still many problems to be solved about this device-based therapy [9]. Here, we critically summarize the prospect of RDN's role in clinical practice and seemingly validated the effects of RDN on long-term outcomes in patients with RH.

\section{Available evidence}

We only included trials with a follow-up time of more than 12 months to reassess the effects of EDN on longterm outcomes in patients with RH. Based on our previous work [9], we included a total of nine typical clinical trials with a maximum follow-up of 3 years (EnligHTN I [10], EnligHTN III [11], Global SYMPLICITY Registry [12], Krum [13], RAPID [14], REDUCE-HTN [15], Symplicity HTN-1 [16], Symplicity HTN-2 [17], and Symplicity HTN-3 [18]) in this study. The baseline information is shown in Table 1; Fig. 1A-C.

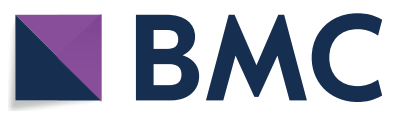

c) The Author(s) 2021. This article is licensed under a Creative Commons Attribution 4.0 International License, which permits use, sharing, adaptation, distribution and reproduction in any medium or format, as long as you give appropriate credit to the original author(s) and the source, provide a link to the Creative Commons licence, and indicate if changes were made. The images or other third party material in this article are included in the article's Creative Commons licence, unless indicated otherwise in a credit line to the material. If material is not included in the article's Creative Commons licence and your intended use is not permitted by statutory regulation or exceeds the permitted use, you will need to obtain permission directly from the copyright holder. To view a copy of this licence, visit http://creativecommons.org/licenses/by/4.0/. The Creative Commons Public Domain Dedication waiver (http://creativecommons.org/publicdomain/zero/1.0/) applies to the data made available in this article, unless otherwise stated in a credit line to the data. 
Table 1 The baseline information of major trials

\begin{tabular}{|c|c|c|c|c|c|}
\hline Trials & Country & Patients & Study design & Indicators & Follow-up (months) \\
\hline EnligHTN I & Australia & 46 & $\begin{array}{l}\text { First-in-human, prospective, } \\
\text { multi-centre, non-randomized } \\
\text { study }\end{array}$ & $\mathrm{OBP}$ and $\mathrm{ABPM}$ & 12 \\
\hline EnligHTN III & Australia and New Zealand & 39 & $\begin{array}{l}\text { First-in-human, prospective, } \\
\text { multi-center, non-randomized } \\
\text { study }\end{array}$ & $\mathrm{OBP}$ and $\mathrm{ABPM}$ & 12,24 \\
\hline Global SYMPLICITY Registry & $\begin{array}{l}\text { Canada, Western Europe, Latin } \\
\text { America, Eastern Europe, South } \\
\text { Africa, Middle East, Asia, Aus- } \\
\text { tralia, and New Zealand }\end{array}$ & 2237 & $\begin{array}{l}\text { Prospective, open-label, single- } \\
\text { arm, observational registry }\end{array}$ & $\mathrm{OBP}$ and $\mathrm{ABPM}$ & $12,24,36$ \\
\hline Krum & Australian and European & 45 & Single-arm & OBP & 12 \\
\hline RAPID & Europe and New Zealand & 50 & $\begin{array}{l}\text { Prospective, multicentre, single- } \\
\text { arm study }\end{array}$ & $\mathrm{OBP}$ and $\mathrm{ABPM}$ & 12 \\
\hline REDUCE-HTN & Germany & 146 & $\begin{array}{l}\text { Prospective, multicentre, single- } \\
\text { arm study }\end{array}$ & $\mathrm{OBP}$ and $\mathrm{ABPM}$ & 12,24 \\
\hline Symplicity HTN-1 & Australia, Europe, and USA & 153 & Single-arm & $\mathrm{OBP}$ & $12,24,36$ \\
\hline Symplicity HTN-2 & Australia & 106 & $\begin{array}{l}\text { Randomized controlled crossover- } \\
\text { trial }\end{array}$ & $\mathrm{OBP}$ & 12,36 \\
\hline Symplicity HTN-3 & United States & 535 & $\begin{array}{l}\text { Prospective, single-blind, } \\
\text { crossover, randomized, sham- } \\
\text { controlled trial }\end{array}$ & $\mathrm{OBP}$ and $\mathrm{ABPM}$ & 12 \\
\hline
\end{tabular}

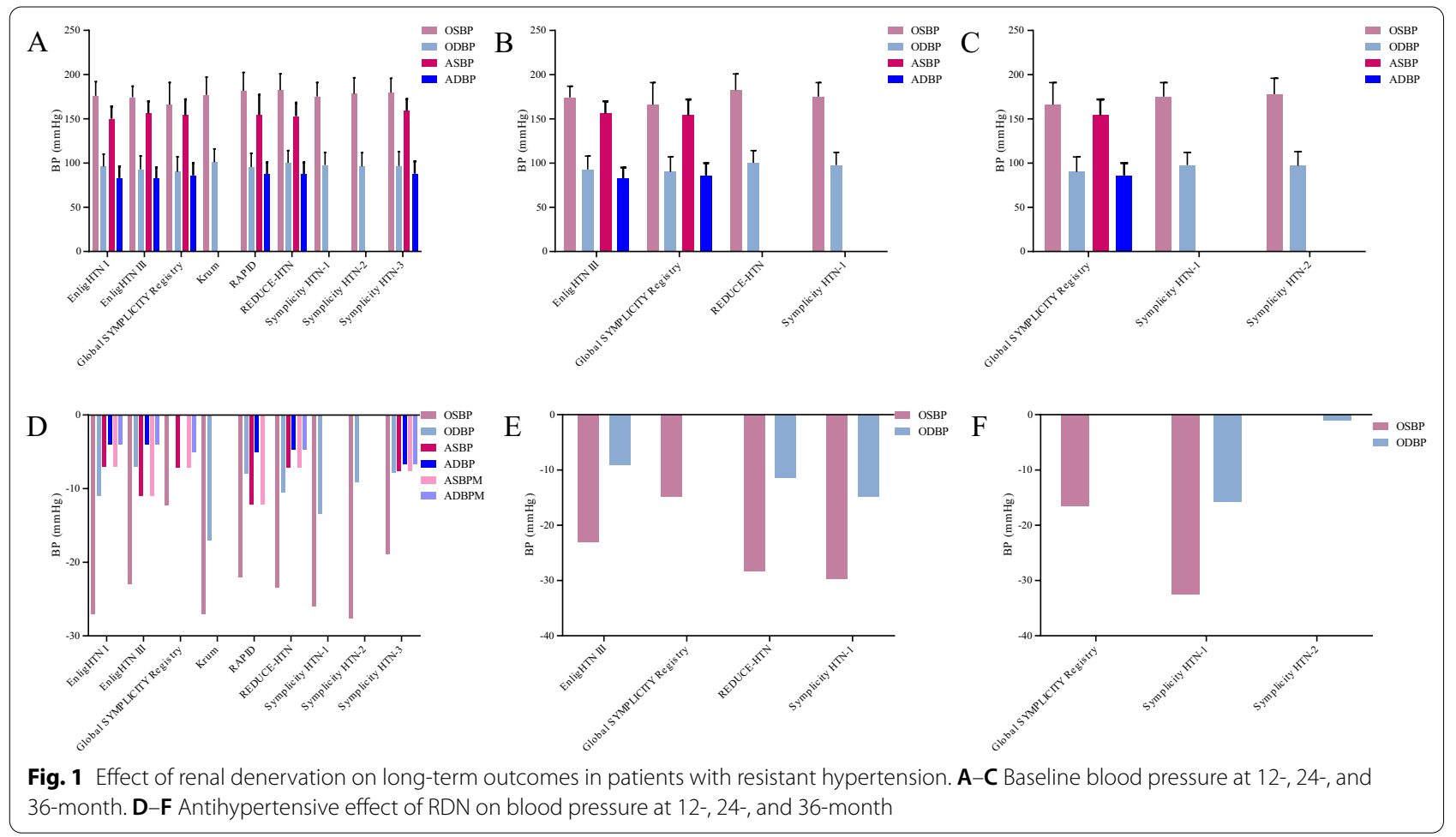

Office BP (OBP), the most easily obtained indication in patients with hypertension, can directly and objectively evaluate the effect of BP reduction in those populations. All trials reported OBP. Notably, Global SYMPLICITY Registry [12] only reported office systolic BP (OSBP).
During the 12-month follow-up, OSBP was reduced with a median range from 12.3 to $23.6 \mathrm{mmHg}$, while office diastolic BP (ODBP) was reduced with a median range from 7.0 to $13.4 \mathrm{mmHg}$ (Fig. 1D). A total of four trials reported 24-month follow-up data. At 24 months, the 
antihypertensive effect of RDN was better than that of 12 months, regardless of OSBP and ODBP (Fig. 1E). At 36 months of follow-up, we obtained more encouraging results (Fig. 1F), except for Symplicity HTN-2 [17].

Ambulatory BP monitoring (ABPM) is recommended for the initial evaluation of all newly diagnosed persons with hypertension and evaluation of antihypertensive efficacy in BP trials [19]. However, among nine trials, only six trials reported ABPM. As OBP, ABPM can achieve better results with the extension of follow-up time (Fig. 1D).

\section{Limitations and future perspectives}

Our results must be viewed in light of the limitations of this analysis. Differences in procedural aspects, postprocedural management, and follow-up protocol may have existed between the included trials. In addition, some trials are single-arm trials, so we lack a positive control or sham control. Thirdly, in order to evaluate the results of RDN on long-term follow-up, we have to omit some short-term follow-up trials, such as Symplicity HTNJapan [20], DENERHTN [21], SPYRAL HTN-OFF MED [22], SPYRAL HTN-ON MED [23], RADIANCE-HTN SOLO [24], and SPYRAL HTN-OFF MED Pivotal [25]. Moreover, not all trials reported ABPM, which limits our assessment of the impact of RDN on ABPM. Finally, different RDN systems, such as OneShot ${ }^{\text {TM }}$ ablation system [14], EnligHTN ${ }^{\mathrm{TM}}$ multi-electrode system $[10,26]$, second-generation EnligHTN ${ }^{\mathrm{TM}}$ system [11], and Vessix System $[15,27]$, were not investigated.

What else then is needed before accepting RDN as a safe and effective therapy for RH? The extent of RDN during the operation and the patency of renal nerve fibers at the later stage after ablation may be the next hurdle we need to overcome. Other important issues will need to be addressed in the future such as the effect of RDN on reducing the number of drugs (or drug dosages) for longterm BP control and hard endpoint data, such as cardiovascular outcomes. With the development of RDN, the continuous innovation of RDN technology and methods, the development about better evaluating the real-time success of RDN, and the improvement for identifying individuals who are most likely to benefit from RDN will ultimately determine whether RDN represents a feasible way to manage $\mathrm{RH}$ in the future.

Efferent (sympathetic) and afferent (sensory) fibers compose renal nerves, which coordinate renal function, central hemodynamics, and BP. Renal efferent nerves could increase renin secretion, promote tubular sodium reabsorption, and regulate renal blood flow [28], and these functions are proposed to underlie the antihypertensive effects of RDN [29, 30]. Experimentally, the stimulation of renal afferent fibers in animals elevates
BP [31], and renal afferent nerve activity is increased in deoxycorticosterone-salt rats [32] and renovascular hypertensive mice [31]. In these models, dorsal rhizotomy or selective chemical ablation of renal afferent fibers reduces $\mathrm{BP}$ to the same extent as total renal denervation [31]. However, the mechanism responsible for the antihypertensive effect of RDN is still unclear. An elevated BP coupled to increased sympathetic drive [33, 34]. Specifically targeting afferent renal nerves in deoxycorticosterone acetate-salt model [32, 35, 36] or efferent nerves in Dahl salt-sensitive rats [37] chronically lower BP. More studies are needed to determine the importance of afferent or efferent fibers in the antihypertensive effect of RDN. However, current evidence does not support the dominant role of afferent or efferent nerves in the antihypertensive effect of RDN. A previous study points that global neurogenic pressor activity was significantly lower in $\mathrm{BPH} / 2 \mathrm{~J}$ mice 14 days after RDN, thereby, sympathetic control of either the renal vasculature (via efferents), or the nonrenal vasculature and heart (via afferents), are increased in hypertensive BPH/2J mice [33]. However, another study reported that global neurogenic pressor activity, assessed using the ganglion blocker pentolinium, was normal in $\mathrm{BPH} / 2 \mathrm{~J}$ mice after RDN [38]. That is to say, there is still a long way to go.

Moreover, the mechanism of $\mathrm{RDN}$ on $\mathrm{RH}$ needs to be further explored. A sustained fall in BP induced by RDN was associated with a reduction of intrarenal renin expression [38]. The lack of inhibition of the depressor effects of pentolinium and enalaprilat by RDN suggests that vasoconstrictor effects of the sympathetic nervous system or renin-angiotensin-aldosterone system are not involved [38]. Another study also confirmed RDN did not result in a significant change in endogenous catecholamines or renin-angiotensin-aldosterone system hormones at 6 months despite significant reductions in $\mathrm{BP}$ [39]. On the contrary, some hold that RDN is thought to interrupt the sympathetic-mediated neurohormonal pathway as part of its mechanism of action to reduce BP $[40,41]$. In certain animal models, RDN demonstrated a reduction of renal tissue norepinephrine and plasma renin activity [42], a downregulation of the ACE/Ang II/ AT1R axis, and upregulation of the ACE2/Ang-(1-7)/ MasR axis in the kidney [43]. Clinically, these results are elusive and confounded. RDN noted a significant decrease in plasma renin activity $[44,45]$. The greater the plasma renin activity, the more obvious the antihypertensive effect [45]. More studies indicated plasma renin activity did not significantly change post-RDN [46-48]. RDN also reduced whole-body norepinephrine spillover [49], did not significantly change plasma catecholamines [46], and had a mixed influence on aldosterone $[45,47,48,50]$. In addition, arterial stiffness is a leading 
biomarker of risk in hypertension [51], and ferritin represents an independent risk factor of arterial stiffness [52]. However, the close relationship between ferritin and $\mathrm{RH}$ still needs further study.

\section{Conclusions}

RDN may be one of the effective ways to reduce BP in patients with $\mathrm{RH}$, but there are still many problems to be solved. The first is the nature of the study needs to be a double-blind, sham-controlled study. In addition, for the evaluation of BP, ambulatory BP needs to be the first choice. Finally, the continuous antihypertensive effect of RDN in different RDN systems also needs to be strictly compared. Still, we are seeing light at the end of the tunnel.

\section{Abbreviations}

$\mathrm{RH}$ : Resistance hypertension; BP: Blood pressure; RDN: Renal denervation; OBP: Office blood pressure; OSBP: Office systolic blood pressure; ODBP: Office diastolic blood pressure; ABPM: Ambulatory blood pressure monitoring.

\section{Acknowledgements}

We thank all scientists and participants involved in resistant hypertension.

\section{Authors' contributions}

$\mathrm{BL}$ and NG conceived, designed, or planned the idea. All authors collected and read the literature. BL drafted the manuscript. NG revised the manuscript. All authors read and approved the final manuscript.

\section{Funding}

This work was partly supported by National Natural Science Foundation of China [81774229], Research and Practice Innovation Plan for Postgraduates of Jiangsu, China, Jiangsu Universities Nursing Advantage Discipline Project [2019YSHL095], and Jiangsu Leading Talent Project of Traditional Chinese Medicine [Jiangsu TCM 2018 No. 4].

\section{Availability of data and materials}

Not applicable.

\section{Declarations}

Ethics approval and consent to participate

Not applicable.

\section{Consent for publication}

Not applicable.

\section{Competing interests}

The authors declare that they have no competing interests.

\section{Author details}

${ }^{1}$ Nanjing University of Chinese Medicine, Nanjing, China. ${ }^{2}$ Southwest Medical University, Luzhou, China. ${ }^{3}$ Nanjing Hospital of Chinese Medicine Affiliated to Nanjing University of Chinese Medicine, Nanjing, China.

Received: 16 May 2021 Accepted: 28 May 2021

Published online: 05 June 2021

\section{References}

1. Whelton PK, Carey RM, Aronow WS, Casey DE, Collins KJ, Dennison Himmelfarb C, De Palma SM, Gidding S, Jamerson KA, Jones DW, et al. 2017
ACC/AHA/AAPA/ABC/ACPM/AGS/APhA/ASH/ASPC/NMA/PCNA guideline for the prevention, detection, evaluation, and management of high blood pressure in adults: a report of the American College of Cardiology/ American HeartAssociation Task Force on Clinical Practice Guidelines. Hypertension. 2018;71(6):1269-324.

2. Smith SM, Gurka MJ, Winterstein AG, Pepine CJ, Cooper-DeHoff RM. Incidence, prevalence, and predictors of treatment-resistant hypertension with intensive blood pressure lowering. J Clin Hypertens. 2019;21(6):825-34.

3. Kaczmarski KR, Sozio SM, Chen J, Sang Y, Shafi T. Resistant hypertension and cardiovascular disease mortality in the US: results from the National Health and Nutrition Examination Survey (NHANES). BMC Nephrol. 2019;20(1):138.

4. Lay-Flurrie SL, Sheppard JP, Stevens RJ, Mallen C, Heneghan C, Hobbs FDR, Williams B, Mant J, McManus RJ. Impact of changes to national hypertension guidelines on hypertension management and outcomes in the United Kingdom. Hypertension. 2020;75(2):356-64.

5. Sinnott S-J, Smeeth L, Williamson E, Douglas IJ. Trends for prevalence and incidence of resistant hypertension: population based cohort study in the UK 1995-2015. BMJ. 2017;358:3984.

6. Pio-Abreu A, Drager LF. Resistant hypertension: time to consider the best fifth anti-hypertensive treatment. Curr Hypertens Rep. 2018;20(8):67.

7. Kinguchi S, Wakui H, Ito Y, Kondo Y, Azushima K, Osada U, Yamakawa T, Iwamoto T, Yutoh J, Misumi T, et al. Improved home BP profile with dapagliflozin is associated with amelioration of albuminuria in Japanese patients with diabetic nephropathy: the Yokohama add-on inhibitory efficacy of dapagliflozin on albuminuria in Japanese patients with type 2 diabetes study (Y-AIDA study). Cardiovasc Diabetol. 2019;18(1):110.

8. Kandzari DE. Renal denervation for hypertension: what is needed, and what is next. Eur Heart J. 2019;40(42):3483-5.

9. Liang B, Zhao Y-X, Gu N. Renal denervation for resistant hypertension: where do we stand? Curr Hypertens Rep. 2020;22(10):83.

10. Papademetriou V, Tsioufis CP, Sinhal A, Chew DP, Meredith IT, Malaiapan $Y$, Worthley MI, Worthley SG. Catheter-based renal denervation for resistant hypertension: 12-month results of the EnligHTN I first-in-human study using a multielectrode ablation system. Hypertension. 2014;64(3):565-72.

11. Worthley SG, Wilkins GT, Webster MW, Montarello JK, Delacroix S, Whitbourn RJ, Warren RJ. Safety and performance of the second generation EnligHTN ${ }^{\mathrm{TM}}$ Renal Denervation System in patients with drug-resistant, uncontrolled hypertension. Atherosclerosis. 2017;262:94-100.

12. Mahfoud F, Böhm M, Schmieder R, Narkiewicz K, Ewen S, Ruilope L, Schlaich M, Williams B, Fahy M, Mancia G. Effects of renal denervation on kidney function and long-term outcomes: 3-year follow-up from the Global SYMPLICITY Registry. Eur Heart J. 2019;40(42):3474-82.

13. Krum H, Schlaich M, Whitbourn R, Sobotka PA, Sadowski J, Bartus K, Kapelak B, Walton A, Sievert H, Thambar S, et al. Catheter-based renal sympathetic denervation for resistant hypertension: a multicentre safety and proof-of-principle cohort study. Lancet. 2009;373(9671):1275-81.

14. Verheye S, Ormiston J, Bergmann MW, Sievert H, Schwindt A, Werner N, Vogel B, Colombo A. Twelve-month results of the rapid renal sympathetic denervation for resistant hypertension using the OneShotTM ablation system (RAPID) study. Eurolntervention. 2015;10(10):1221-9.

15. Sievert H, Schofer J, Ormiston J, Hoppe UC, Meredith IT, Walters DL, Azizi M, Diaz-Cartelle J. Bipolar radiofrequency renal denervation with the Vessix catheter in patients with resistant hypertension: 2-year results from the REDUCE-HTN trial. J Hum Hypertens. 2017;31(5):366-8.

16. Krum H, Schlaich MP, Sobotka PA, Böhm M, Mahfoud F, Rocha-Singh K, Katholi R, Esler MD. Percutaneous renal denervation in patients with treatment-resistant hypertension: final 3-year report of the Symplicity HTN-1 study. Lancet. 2014;383(9917):622-9.

17. Esler MD, Böhm M, Sievert H, Rump CL, Schmieder RE, Krum H, Mahfoud F, Schlaich MP. Catheter-based renal denervation for treatment of patients with treatment-resistant hypertension: 36 month results from the SYMPLICITY HTN-2 randomized clinical trial. Eur Heart J. 2014;35(26):1752-9.

18. Bakris GL, Townsend RR, Flack JM, Brar S, Cohen SA, D'Agostino R, Kandzari $D E$, Katzen BT, Leon MB, Mauri L, et al. 12-month blood pressure results of catheter-based renal artery denervation for resistant hypertension: the SYMPLICITY HTN-3 trial. J Am Coll Cardiol. 2015;65(13):1314-21.

19. Bakris GL, Townsend RR, Liu M, Cohen SA, D'Agostino R, Flack JM, Kandzari $D E$, Katzen BT, Leon MB, Mauri L, et al. Impact of renal denervation on 
24-hour ambulatory blood pressure: results from SYMPLICITY HTN-3. J Am Coll Cardiol. 2014;64(11):1071-8.

20. Kario K, Ogawa H, Okumura K, Okura T, Saito S, Ueno T, Haskin R, Negoita M, Shimada K. SYMPLICITY HTN-Japan—first randomized controlled trial of catheter-based renal denervation in asian patients. Circ J. 2015;79(6):1222-9.

21. Azizi M, Sapoval M, Gosse P, Monge M, Bobrie G, Delsart P, Midulla M, Mounier-Véhier C, Courand P-Y, Lantelme P, et al. Optimum and stepped care standardised antihypertensive treatment with or without renal denervation for resistant hypertension (DENERHTN): a multicentre, openlabel, randomised controlled trial. Lancet. 2015;385(9981):1957-65.

22. Townsend RR, Mahfoud F, Kandzari DE, Kario K, Pocock S, Weber MA, Ewen S, Tsioufis K, Tousoulis D, Sharp ASP, et al. Catheter-based renal denervation in patients with uncontrolled hypertension in the absence of antihypertensive medications (SPYRAL HTN-OFF MED): a randomised, sham-controlled, proof-of-concept trial. Lancet. 2017;390(10108):2160-70.

23. Kandzari DE, Böhm M, Mahfoud F, Townsend RR, Weber MA, Pocock S, Tsioufis K, Tousoulis D, Choi JW, East C, et al. Effect of renal denervation on blood pressure in the presence of antihypertensive drugs: 6-month efficacy and safety results from the SPYRAL HTN-ON MED proof-of-concept randomised trial. Lancet. 2018;391(10137):2346-55.

24. Azizi M, Schmieder RE, Mahfoud F, Weber MA, Daemen J, Davies J, Basile J, Kirtane AJ, Wang Y, Lobo MD, et al. Endovascular ultrasound renal denervation to treat hypertension (RADIANCE-HTN SOLO): a multicentre, international, single-blind, randomised, sham-controlled trial. Lancet. 2018;391(10137):2335-45.

25. Böhm M, Kario K, Kandzari DE, Mahfoud F, Weber MA, Schmieder RE, Tsioufis K, Pocock S, Konstantinidis D, Choi JW, et al. Efficacy of catheterbased renal denervation in the absence of antihypertensive medications (SPYRAL HTN-OFF MED Pivotal): a multicentre, randomised, sham-controlled trial. Lancet. 2020;395(10234):1444-51.

26. Worthley SG, Tsioufis CP, Worthley MI, Sinhal A, Chew DP, Meredith IT, Malaiapan Y, Papademetriou V. Safety and efficacy of a multi-electrode renal sympathetic denervation system in resistant hypertension: the EnligHTN I trial. Eur Heart J. 2013;34(28):2132-40.

27. Sievert H, Schofer J, Ormiston J, Hoppe UC, Meredith IT, Walters DL, Aziz M, Diaz-Cartelle J, Cohen-Mazor M. Renal denervation with a percutaneous bipolar radiofrequency balloon catheter in patients with resistant hypertension: 6-month results from the REDUCE-HTN clinical study. Eurolntervention. 2015;10(10):1213-20.

28. DeLalio $\sqcup$, Sved AF, Stocker SD. Sympathetic nervous system contributions to hypertension: updates and therapeutic relevance. Can J Cardiol. 2020;36(5):712-20.

29. Osborn JW, Foss JD. Renal nerves and long-term control of arterial pressure. Comp Physiol. 2017;7(2):263-320.

30. Fisher JP, Paton JFR. The sympathetic nervous system and blood pressure in humans: implications for hypertension. J Hum Hypertens. 2012;26(8):463-75.

31. Ong J, Kinsman BJ, Sved AF, Rush BM, Tan RJ, Carattino MD, Stocker SD. Renal sensory nerves increase sympathetic nerve activity and blood pressure in 2-kidney 1-clip hypertensive mice. J Neurophysiol. 2019:122(1):358-67.

32. Banek CT, Knuepfer MM, Foss JD, Fiege JK, Asirvatham-Jeyaraj N, Van Helden D, Shimizu Y, Osborn JW. Resting afferent renal nerve discharge and renal inflammation: elucidating the role of afferent and efferent renal nerves in deoxycorticosterone acetate salt hypertension. Hypertension (Dallas, Tex: 1979). 2016;68(6):1415-23.

33. Asirvatham-Jeyaraj N, Gauthier MM, Banek CT, Ramesh A, Garver H, Fink GD, Osborn JW. Renal denervation and celiac ganglionectomy decrease mean arterial pressure similarly in genetically hypertensive schlager (BPH/2J) mice. Hypertension (Dallas, Tex: 1979). 2021;77(2):519-28.

34. Jackson KL, Head GA, Gueguen C, Stevenson ER, Lim K, Marques FZ. Mechanisms responsible for genetic hypertension in schlager $\mathrm{BPH} / 2$ mice. Front Physiol. 2019;10:1311.

35. Banek CT, Gauthier MM, Van Helden DA, Fink GD, Osborn JW. Renal inflammation in DOCA-salt hypertension. Hypertension. 2019;73(5):1079-86.
36. Banek CT, Gauthier MM, Baumann DC, Van Helden D, Asirvatham-Jeyaraj N, Panoskaltsis-Mortari A, Fink GD, Osborn JW. Targeted afferent renal denervation reduces arterial pressure but not renal inflammation in established DOCA-salt hypertension in the rat. Am J Physiol Regul Integr Comp Physiol. 2018;314(6):R883-91.

37. Foss JD, Fink GD, Osborn JW. Differential role of afferent and efferent renal nerves in the maintenance of early- and late-phase Dahl S hypertension. Am J Physiol Regul Integr Comp Physiol. 2016;310(3):R262-7.

38. Gueguen C, Jackson KL, Marques FZ, Eikelis N, Phillips S, Stevenson ER, Charchar FJ, Lambert GW, Davern PJ, Head GA. Renal nerves contribute to hypertension in Schlager BPH/2J mice. Hypertens Res. 2019;42(3):306-18.

39. Feyz L, van den Berg S, Zietse R, Kardys I, Versmissen J, Daemen J. Effect of renal denervation on catecholamines and the renin-angiotensinaldosterone system. J Renin Angiotensin Aldosterone System: JRAAS. 2020;21(3):1470320320943095.

40. Unger T, Paulis L, Sica DA. Therapeutic perspectives in hypertension: novel means for renin-angiotensin-aldosterone system modulation and emerging device-based approaches. Eur Heart J. 2011;32(22):2739-47.

41. Messerli FH, Bavishi C, Bangalore S. Renal Denervation in Hypertension: Barking Up the Wrong Tree? J Am Coll Cardiol; 2021.

42. Machino T, Murakoshi N, Sato A, Xu D, Hoshi T, Kimura T, Aonuma K. Antihypertensive effect of radiofrequency renal denervation in spontaneously hypertensive rats. Life Sci. 2014;110(2):86-92.

43. Wang M, Han W, Zhang M, Fang W, Zhai X, Guan S, Qu X. Long-term renal sympathetic denervation ameliorates renal fibrosis and delays the onset of hypertension in spontaneously hypertensive rats. Am J Transl Res. 2018;10(12):4042-53.

44. Hamza M, Khamis H. Renal sympathetic denervation for treatment of resistant hypertension: Egyptian experience. J Interv Cardiol. 2014;27(4):423-7.

45. Mahfoud F, Townsend RR, Kandzari DE, Kario K, Schmieder RE, Tsioufis K, Pocock S, David S, Patel K, Rao A, et al. Changes in plasma renin activity after renal artery sympathetic denervation. J Am Coll Cardiol 2021.

46. Dobrowolski LC, Eeftinck Schattenkerk DW, Krediet CTP, Van Brussel PM, Vogt L, Bemelman FJ, Reekers JA, Van Den Born B-JH, Verberne HJ. Renal sympathetic nerve activity after catheter-based renal denervation. EJNMMI Res. 2018;8(1):8.

47. Voskuil M, Verloop WL, Blankestijn PJ, Agostoni P, Stella PR, Doevendans PA. Percutaneous renal denervation for the treatment of resistant essential hypertension; the first Dutch experience. Netherlands Heart J. 2011;19(7-8):319-23.

48. Ewen S, Cremers B, Meyer MR, Donazzan L, Kindermann I, Ukena C, Helfer AG, Maurer HH, Laufs U, Grassi G, et al. Blood pressure changes after catheter-based renal denervation are related to reductions in total peripheral resistance. J Hypertens. 2015;33(12):2519-25.

49. Schlaich MP, Sobotka PA, Krum H, Lambert E, Esler MD. Renal sympathetic-nerve ablation for uncontrolled hypertension. N Engl J Med. 2009;361(9):932-4.

50. Grassi G, Seravalle G, Brambilla G, Trabattoni D, Cuspidi C, Corso R, Pieruzzi F, Genovesi S, Stella A, Facchetti R, et al. Blood pressure responses to renal denervation precede and are independent of the sympathetic and baroreflex effects. Hypertension (Dallas, Tex: 1979). 2015;65(6):1209-16.

51. Boutouyrie P, Chowienczyk P. Humphrey JD, Mitchell GF. Arterial stiffness and cardiovascular risk in hypertension. Circ Res. 2021;128(7):864-86.

52. Sciacqua A, Ventura E, Tripepi G, Cassano V, D'Arrigo G, Roumeliotis S, Maio R, Miceli S, Perticone M, Andreozzi F, et al. Ferritin modifies the relationship between inflammation and arterial stiffness in hypertensive patients with different glucose tolerance. Cardiovasc Diabetol. 2020;19(1):123.

\section{Publisher's Note}

Springer Nature remains neutral with regard to jurisdictional claims in published maps and institutional affiliations. 